\title{
Optimization of Spirulina platensis Culture Media as an Effort for Utilization of
} Pangasius Farming Waste Water

\author{
Marini Wijayanti ${ }^{1, *}$, Dade Jubaedah ${ }^{1}$, Nuni Gofar ${ }^{2}$, Devi Anjastari ${ }^{3}$ \\ ${ }^{1}$ Aquaculture Program, Department of Fisheries, Faculty of Agriculture, Universitas Sriwijaya \\ ${ }^{2}$ Department of Soil Science, Faculty of Agriculture, Universitas Sriwijaya \\ ${ }^{3}$ Student of Aquaculture, Department of Fisheries, Fuculty of Agriculture, Universitas Sriwijaya \\ Jl. Raya Palembang-Prabumulih KM.32 Indralaya, Ogan Ilir, South Sumatera, Indonesia \\ *Corresponding Author: e-mail address : mariniwijayanti@fp.unsri.ac.id
}

Article history

\begin{tabular}{lllc}
\hline Received & Received from reviced & Accepted & Available online \\
28 November 2018 & 07 January 2019 & 10 January 2019 & 11 January 2019 \\
\hline
\end{tabular}

\begin{abstract}
Pangasius is a fast-growing fish species that has great potential for production and export growth in Indonesia. Their farming produces a lot of organic material and ammonia which potentially make polution in freshwater body. The wastewater can be used for high value microalgal cultivation media. The microalgae are used in various fields, one of those is Spirulina platensis, a spiral blue green algae. This aims of this study was to determine the best composition of the technical fertilizer in the pond waste of Pangasius farming pond to obtain maximum density and know the spesific growth rate of Spirulina platensis. The research method used Completely Randomized Design (CRD) with 6 treatments (3 replication), $\mathrm{P}_{0}$ using $100 \%$ technical fertilizer without using Pangasius waste water while $\mathrm{P}_{1}-\mathrm{P}_{5}$ use $0 \%\left(\mathrm{P}_{1}\right), 25 \%\left(\mathrm{P}_{2}\right), 50 \%\left(\mathrm{P}_{3}\right), 75 \%\left(\mathrm{P}_{4}\right)$ and $100 \%\left(\mathrm{P}_{5}\right)$ technical fertilizer using Pangasius farming waste water. The most efficient treatment obtained $23.90 \mathrm{gL}^{-1}$ maximum density, $6.22 \% . \mathrm{d}^{-1}$ specific growth rate and $87.77 \%$ ammonia removal.
\end{abstract}

Keywords: Spirulina, Pangasius farming, waste water, culture media

Abstrak (Indonesian): Pangasius adalah spesies ikan cepat tumbuh yang memiliki potensi besar untuk produksi dan pertumbuhan ekspor di Indonesia. Pemeliharaannya menghasilkan banyak bahan organik dan amonia yang berpotensi membuat polusi dalam tubuh air tawar. Air limbah dapat digunakan untuk media budidaya mikroalga bernilai tinggi. Mikroalga digunakan di berbagai bidang, salah satunya adalah Spirulina platensis, ganggang hijau biru spiral. Tujuan penelitian ini adalah untuk menentukan komposisi pupuk teknis terbaik dalam kolam tambak budidaya Pangasius untuk mendapatkan kepadatan maksimum dan mengetahui tingkat pertumbuhan spesifik Spirulina platensis. Metode penelitian menggunakan Rancangan Acak Lengkap (RAL) dengan 6 perlakuan ( 3 ulangan), P0 menggunakan pupuk teknis 100\% tanpa menggunakan air limbah Pangasius sedangkan P1-P5 menggunakan 0\% (P1), 25\% (P2), $50 \%$ (P3) ), 75\% (P4) dan 100\% (P5) pupuk teknis menggunakan air limbah pertanian Pangasius. Perlakuan yang paling efisien diperoleh 23,90 gL-1 kepadatan maksimum, laju pertumbuhan spesifik $6,22 \% \cdot \mathrm{h}^{-1}$ dan penghapusan amonia mencapai $87,77 \%$.

Katakunci: Spirulina, pembesaran patin pangasius, air limbah, media kultur

\section{Introduction}

Pangasius is a fast-growing fish species that has great potential for production and export growth in Indonesia. Henriksson et al. (2017) [1] showed that $1000 \mathrm{~kg}$ Pangasius production in $195 \mathrm{~m}^{2}$ pond system will produce $0.43 \mathrm{~kg}$ Ammonia, $0.79 \mathrm{~kg}$ Nitrous oxide, $34.2 \mathrm{~kg}$ Ammonium, $14.7 \mathrm{~kg}$ Nitrate, $1.93 \mathrm{~kg}$ Nitrogen, and 1,54 kg Phosphorus as environmental output. Their farming produces a lot of organic material and ammonia which potentially make polution around freshwater. The wastewater can be spend for high value microalgal cultivation media before releasing to environtment. Cyanobacterias have potential for growth using solar energy and large quantities of nutrients effluents rich in inorganic pollutants, such as nitrogen and phosphate. They are an alternative for decreasing cost of large scale production. This production became treatment of the wastewaters occur through removal of the pollutants [2].

The high value microalgae like a cyanobacteria, S.platensis. It has several characteristics and nutrients that are suitable as functional foods, feed, and nutracheutical [3]. Spirulina have known for its high protein content and therapeutic properties which has been studied as a potential source of bioactive peptides for their ability to offer specific health benefits, such as antimicrobial, antiallergic, antihypertensive, antitumor, and immunomodulatory properties [4]. Spirulina platensis was successfully 
cultured using organic nutrients from liquid waste, such as molasses [5], tofu and latex liquid waste [6], Palm Oil Mill Effluent/ POME [7] and vinasse from anaerobic processing [8].

Therefore, this study was carried out to examine the effect of Pangasius catfish culture waste which was added to fertilizer for Spirulina media. The growth of microalgae can remediate fish farm wastewater because aquaculture wastewater contains good organic material and ammonia to increase the density of $S$. platensis. Production of Spirulina platensis is good for removing ammonia and nitrate found in fish pond waste water [9].

Spirulina platensis can remove the nutrients dissolved on the fish Nile tilapia culture effluent with density of $S$. platensis resulted in the production of $0.22 \mathrm{~g} \mathrm{~L}^{-1}$ of dry biomass and maximum productivity of $0.03 \mathrm{~g} \mathrm{~L}^{-1}$ day $^{-1}$. The S. platensis were capable of reducing the nitrite, nitrate and phosphate levels by 100; 98.7 and $94.8 \%$, respectively [10]. The process of Pangasius catfish cultivation produces waste that can pollute the environment. This study is expected to reduce the impact of environmental pollution by utilizing Pangasius catfish pond wastewater for the growth media of $S$. platensis and to determine the best composition of technical fertilizers in the utilization.

\section{Material and Methods}

\subsection{Acquiring the Spirulina platensis}

The strain with $1000 \mathrm{~mL}$ of S. platensis was cultured from a aquaculture laboratory at Aquaculture Study Program, Fisheries Department, Faculty of Agriculture, Universitas Sriwijaya. Its volume was increased on scaling up to a maximum of $5 \mathrm{~L}$ by the addition of the modified technical fertilizer medium [6] with salinity of $1 \%$, remaining under constant aeration and artificial lighting of 1000-1200 lux, termed stock culture.

\subsection{Optical density and biomassa density}

The monitoring of the growth of $S$. platensis cultures was performed daily by measuring the absorbance (optical density - OD) of a sample with $0,005 \mathrm{~L}$ of water from the culture in a spectrophotometer Spectronic G-20, with a wavelength of $560 \mathrm{~nm}$ (Abs560). The biomass density (g. $\left.\mathrm{L}^{-1}\right)$ was approached with :

Biomassa density $=5.9594 .($ Abs560 $)+1.1837$

\subsection{Determining the yield and productivity of the $S$. platensis culture}

To determine the yield and productivity of the S.platensis cultures it was necessary to separate the biomass from the culture medium. In order to do this, five liters of the culture, obtained from phases of the reduced growth, were filtrated with calico cloth. Subsequently, the biomass was dried in a laboratory oven for $48 \mathrm{~h}$ with air renewal at $60{ }^{\circ} \mathrm{C}$.

\subsection{Experimental design}

The experimental design followed six treatments in triplicates (Table1). Pangasius Pangasius pond water waste that has a size of $3 \times 4 \times 1 \mathrm{~m}^{3}$ with a stocking density of 7 ind. $\mathrm{m}^{-3}$ size $40-45 \mathrm{~cm}$ are maintained for 6 months by feeding floating pellets size 5-6 mm (36-38\% protein, $5-6 \%$ fat, $4 \%$ crude fiber, $10 \%$ ash and $11 \%$ moisture content) given twice a day (morning and evening) containing a total nitrogen content of $1.9 \mathrm{mg} . \mathrm{L}^{-1}$, total organic carbon $11.4 \mathrm{mg} . \mathrm{L}^{-1}$, phosphorus $2.6 \mathrm{mg} . \mathrm{L}^{-1}$ and ammonia 0.81 mg. $L^{-1}$. Meanwhile the nutrient content of the technical fertilizer for S. platensis cultivation contained total nitrogen content of $31.94 \mathrm{mg} . \mathrm{L}^{-1}$, total organic carbon $24.05 \mathrm{mg} . \mathrm{L}^{-1}$ and phosphorus $0.07 \mathrm{mg} . \mathrm{L}^{-1}$.

Table 1. Chemical composition of the modified technical fertilizer medium

\begin{tabular}{|c|c|c|c|c|c|c|}
\hline \multirow{3}{*}{$\begin{array}{c}\text { Material } \\
\text { of technical fertilizer }\end{array}$} & \multirow{3}{*}{$\begin{array}{c}\mathrm{P}_{0} \\
\text { (100\% fertilizer) }\end{array}$} & \multicolumn{5}{|c|}{ Treatment } \\
\hline & & \multicolumn{5}{|c|}{$\%$ fertilizer in waster water Pangasius farming } \\
\hline & & $\begin{array}{l}\mathrm{P}_{1} \\
0 \%\end{array}$ & $\begin{array}{c}\mathrm{P}_{2} \\
25 \%\end{array}$ & $\begin{array}{c}\mathrm{P}_{3} \\
50 \%\end{array}$ & $\begin{array}{c}\mathrm{P}_{4} \\
75 \%\end{array}$ & $\begin{array}{c}\mathrm{P}_{5} \\
100 \%\end{array}$ \\
\hline $\mathrm{MgSO}_{4}(\mathrm{~g})$ & 0.6 & - & 0.15 & 0.3 & 0.45 & 0.6 \\
\hline $\mathrm{CaCl}_{2}(\mathrm{~g})$ & 0.12 & - & 0.03 & 0.06 & 0.09 & 0.12 \\
\hline $\mathrm{C}_{10} \mathrm{H}_{16} \mathrm{~N}_{2} \mathrm{O}_{8}(\mathrm{~g})$ & 0.24 & - & 0.06 & 0.12 & 0.18 & 0.24 \\
\hline $\mathrm{Ca}\left(\mathrm{H}_{2} \mathrm{PO}_{4}\right)(\mathrm{g})$ & 1.5 & - & 0.375 & 0.75 & 1.125 & 1.5 \\
\hline$\left(\mathrm{NH}_{2}\right)_{2} \mathrm{CO}(\mathrm{g})$ & 0.9 & - & 0.225 & 0.45 & 0.675 & 0.9 \\
\hline $\mathrm{NH}_{4} \mathrm{SO}_{4}(\mathrm{~g})$ & 3.96 & - & 0.99 & 1.98 & 2.97 & 3.96 \\
\hline $\mathrm{NaHCO}_{3}(\mathrm{~g})$ & 25.5 & - & 6.375 & 12.75 & 19.125 & 25.5 \\
\hline Larutan $\mathrm{AB}_{\text {mix }} *(\mathrm{ml})$ & 3 & - & 0.75 & 1.5 & 6.75 & 3 \\
\hline
\end{tabular}

Note ${ }^{*}=$ modified technical fertilizer medium in $\mathrm{A}_{5}$. 
The growth of cyanobacteria and the nutrients levels in the waters were monitored every day. The calculation of the specific growth rate Spirulina platensis can be performed using a modified formula [11] :

$$
\begin{aligned}
& \mu=\frac{\ln \mathrm{Nt}_{\mathrm{i}}-\ln \mathrm{N}_{0} \times 100 \%}{\mathrm{t}_{\mathrm{i}}} \times 1 \text { daily growth rate }\left(\% \text {. days }{ }^{-1}\right) \\
& \mu=\text { drom } \mathrm{N}_{0} \text { to } \mathrm{Nt} \\
& \mathrm{t}_{\mathrm{i}}=\text { time (days) from }\left(\mathrm{g} \cdot \mathrm{L}^{-1}\right) \\
& \mathrm{N}_{0}=\text { Initial density } \\
& \mathrm{Nt}=\text { density at the time } \mathrm{t}_{\mathrm{i}}\left(\mathrm{g} \cdot \mathrm{L}^{-1}\right)
\end{aligned}
$$

\subsection{Water Quality Parameters}

Monitoring of water quality was done as supporting parameters for the research carried out. Salinity (refractometer, $\mathrm{MW}$ ) and $\mathrm{pH}$ ( $\mathrm{pH}$ meter, MW) were measured daily for experimental period. Value of $\mathrm{pH}$ maintained between 8 to 8.5 and salinity $20 \pm 1$ ppt during the study. The ammonia measurements (American Public Health Association (APHA), 2005) carried out at the beginning and end of the study. The percentages of Ammonia removal presented in the effluents treated by Spirulina platensis were calculated using the following equation: $100 \%$

Ammonia removal $=\left(\left[\mathrm{NH}_{3}\right]_{0}-\left[\mathrm{NH}_{3}\right]_{\mathrm{t}}\right) /\left[\mathrm{NH}_{3}\right]_{0} \quad \mathrm{x}$

\subsection{Statistical Analysis}

The results were submitted to simple analysis of variance tests (ANOVA) $(\mathrm{p}<0.05)$ and in the case of significant differences, the means were compared by the Least Significant Differences test $(\mathrm{p}<0.05)$.

\section{Results and Discussion}

\subsection{Biomass density and specific growth rate}

The highest peak density of $S$. platensis in each treatment was different time. Maximum density in treatment $\mathrm{P} 0$ is $16.31 \mathrm{gL}-1$ on the 8 th day of culture, in treatment $\mathrm{P} 1$ reached $23.90 \mathrm{gL}-1$ on the 10 th day of culture, in treatment $\mathrm{P} 2$ reached $25.09 \mathrm{gL}-1$ on day 10 the culture period, at treatment $\mathrm{P} 3$ reached $19.68 \mathrm{gL}-1$ on the 9th day of culture, P4 treatment reached 18.73 gL-1 on the 10th day of culture and P5 treatment reached $20.78 \mathrm{gL}-1$ on the 10 th day culture. The maximum density of S. platensis in each treatment can be seen in Figure 1.

The highest density of $S$. platensis was found in P2 treatment which had the highest biomass density with an average of 25.09 g.L $\mathrm{L}^{-1}$, while the lowest density was found in treatment P0 which had biomass density 16.31 g. $\mathrm{L}^{-1}$. The high and low density of $S$. platensis is influenced by nutrients found in $S$. platensis cultivation media. The difference of nutrient content in culture media, influences cell quality and density. Technically, microalgae absorbs the content of organic compounds and nutrients in waste, and produces oxygen which can reduce the levels of COD and BOD in waste through the help of organic matter decomposing bacteria [12].

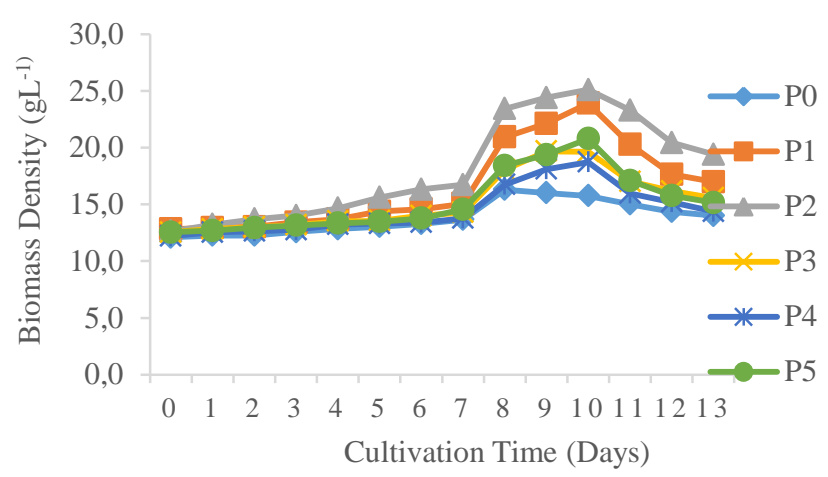

Figure 1. Growth of $S$. platensis in the treatment cultivation medium

The results of the variance analysis showed that the provision of technical fertilizer in Pangasius culture wastewater had a significant effect on the maximum density and specific growth rate of $S$. platensis. The maximum density and specific growth rate of $S$. platensis for each treatment are showed in Table 2.

Table 2. Maximum density of $S$. platensis $\left(\mathrm{g} . \mathrm{L}^{-1}\right)$ and their specific growth $\left(\% . \mathrm{d}^{-1}\right)$

\begin{tabular}{ccc}
\hline Repetition & $\begin{array}{c}\text { Mean } \pm \text { SD } \\
\alpha=2,06\end{array}$ & $\begin{array}{c}\text { Mean } \pm \text { SD } \\
\alpha=0,98\end{array}$ \\
\hline P0 & $16,47 \pm 1,05^{\mathrm{a}}$ & $3,54 \pm 0,67^{\mathrm{a}}$ \\
P1 & $23,90 \pm 1,09^{\mathrm{c}}$ & $6,22 \pm 0,51^{\mathrm{c}}$ \\
P2 & $25,09 \pm 1,50^{\mathrm{c}}$ & $6,85 \pm 0,65^{\mathrm{c}}$ \\
P3 & $20,00 \pm 0,16^{\mathrm{b}}$ & $5,01 \pm 0,33^{\mathrm{b}}$ \\
P4 & $18,73 \pm 1,73^{\mathrm{b}}$ & $4,25 \pm 0,66^{\mathrm{ab}}$ \\
P5 & $20,78 \pm 0,69^{\mathrm{b}}$ & $5,05 \pm 0,40^{\mathrm{b}}$ \\
\hline Note: Thenumbers followedbydifferentsmall supersciptletters show significantdifferences (p<0.05).
\end{tabular}

Based on the LSD test presented in Table 2, it shows that the treatment of $\mathrm{P} 2$ was significantly different than the treatment P0, P3, P4 and P5 but not significantly different from the treatment $\mathrm{P} 1$. Treatment P2 obtained the best maximum density value with a value of $25.09 \%$. However, a more efficient treatment was P1, because treatment P1 used waste media without additional technical fertilizer. While the lowest density was treatment $\mathrm{P} 0$ with a value of $16.47 \%$.

Microalgae can grow well if the nutrients and environment are suitable, if not optimal then microalgae growth will be low. The use of technical fertilizers with high concentrations can reduce water quality and decrease the quality of S. platensis growth. It will also cause discoloration (turbidity) in the cultivation media so that the light penetration decreases which will interfere photosynthesis and production of S. platensis [13]. The population density 
at P0, P3, P4 and P5 is lower than P1 and P2 which shows a relatively high growth pattern.

P2 treatment obtained the best specific growth rate with growth of $6.85 \%$ day-1, while treatment $\mathrm{P} 0$ results in a relatively low growth rate of $3.54 \%$ day- 1 . P2 treatment was significantly different than the treatment P0, P3, P4 and P5 but was not significantly different from treatment $\mathrm{P} 1$, because it was not significantly different between $\mathrm{P} 1$ and $\mathrm{P} 2 \quad(0 \%$ and $25 \%$ ), the most efficient treatment was P1 with waste media without fertilizer for $S$. platensis culture. The difference in specific growth rate in each treatment is caused by the ability of cells to absorb nutrients contained in culture media, not all materials can be directly absorbed and used by cells [14]. In addition, differences in specific growth rates are also influenced by nutritional factors contained in culture media.

The specific growth rate in $\mathrm{P} 2$ treatment due to the administration of $25 \%$ fertilizer mixed with Pangasius cultivation wastewater was in accordance with the nutritional needs of $S$. platensis. Nitrogen is a nutrient that is needed in the formation of chlorophyll, where chlorophyll is needed for photosynthesis and cell growth [15]. When nitrogen concentrations in optimal culture media, cell metabolic activity also goes well, including chlorophyll synthesis, because high chlorophyll content will cause photosynthesis to work well and $S$. platensis growth will be more optimal [16].

The regression relationship between population density (y) and the percentage of technical fertilizer in Pangasius farming pond waste water was shoewd in Figure 2. The polynomial regression analysis results from the average daily population density indicated by the equation $\mathrm{y}=51,237 \mathrm{x} 3-70,549 \mathrm{x} 2+16,191 \mathrm{x}+$ 24,048 with coefficient of determination $\mathrm{R}^{2}=0.9443$.

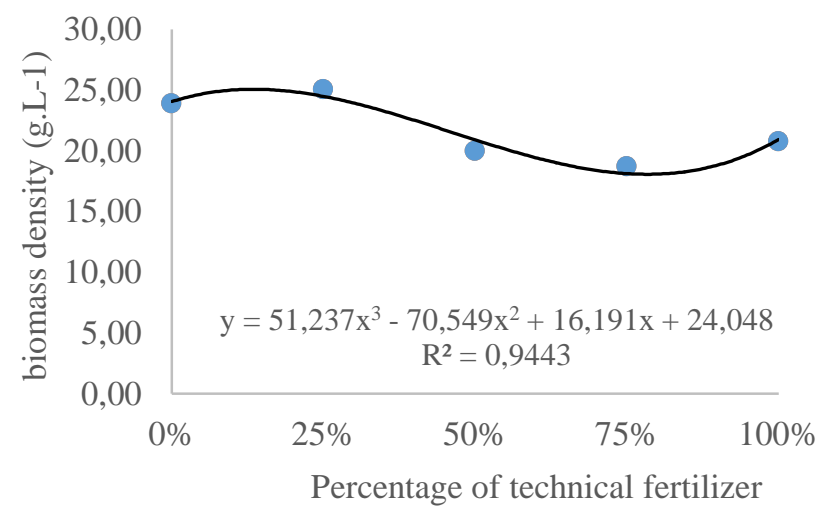

Figure 2. Regression of S. platensis biomass density to percentage of technical fertilizer

Based on the regression equation in Figure 2, it was found that the optimum technical fertilizer concentration was in the range of $13.44 \%$ which resulted in the highest maximum density of $S$. platensis of $25.07 \mathrm{~g} . \mathrm{L}^{-1}$. The level of effectiveness of S. platensis growth is indicated by the increase in biomass production. Addition of $13.44 \%$ of technical fertilizer into Pangasius farming wastewater is thought to be most suitable for the nutritional needs of $S$. platensis.

\subsection{Ammonia removal}

Ammonia is a toxic substance in the waters that is harmful to the health of fish. Ammonia microalgae can be used as nutrients so as to reduce pollution of waters. The percentage of ammonia absorption during the study can be seen in Table 3. Based on the LSD test presented in Table 3, the treatment P2 shows the best ammonia absorption results compared to other treatments, but the treatment of P2 was not significantly different from the treatments P1 and P3, but it was significantly different in the treatments $\mathrm{P} 0$, P4 and P5.

Table 3. Ammonia removal in cultivation medium during S. platensis cultivation (\%)

\begin{tabular}{cc}
\hline & Ammonium Removal \\
Treatment & $\alpha=2,03$ \\
\hline P0 & $81,95 \pm 1,02^{\mathrm{a}}$ \\
P1 & $87,77 \pm 1,01^{\mathrm{c}}$ \\
P2 & $88,07 \pm 1,03^{\mathrm{c}}$ \\
P3 & $87,07 \pm 1,45^{\mathrm{bc}}$ \\
P4 & $80,47 \pm 1,00^{\mathrm{a}}$ \\
P5 & $85,57 \pm 1,24^{\mathrm{b}}$ \\
\hline Note: Thenumbers followedbydifferent small supersciptletters show very significantdifferences $(\mathrm{p}<0.05)$
\end{tabular}

The ability of $S$. platensis to absorb ammonia in wastewater from Pangasius cultivation with the addition of different fertilizer doses has the highest value of $88.07 \%$. During the 13 days of maintenance the ammonia level in the cultivation media diminished. Ammonia was used by microalgae as a nutrient for its growth, which was to help in protein synthesis. Algae requires ammonium for growth. Amanatin and Nurhidayati (2013) [16] showed that ammonium is produced through the dissociation process of ammonium hydroxide. Ammonium hydroxide is ammonia which dissolves in water. Algae must convert nitrate (the main form of nitrogen in water) to ammonium before they can use it. S. platensis utilizes 88.07\% ammonia from Pangasius farming wastewater and from technical fertilizers, so that the density of $S$. platensis has increased. S. platensis is able to absorb ammonia from culture media optimally.

High ammonia can be dangerous for aquatic biota because it is toxic but is different from S. platensis. Yuan et al. (2011) [17] explained that cyanobacteria algae is able to tolerate high ammonia for its growth, but if excessive ammonia will inhibit the growth of $S$. platensis. Effendi (2003) [18] states that an increase in ammonia is influenced by $\mathrm{pH}$. As the $\mathrm{pH}$ increases above 7 in the water, the ammonia percentage will increase as well. S. platensis was cultivated at alkaline medium at $\mathrm{pH} 8-8.5$ so that ammonium was still more 
dominant than ammonia. Control of $\mathrm{pH}$ in a culture medium is very important to maintain the balance of $S$. platensis cell growth.

\section{Conclusion}

Utilization of Pangasius farming wastewater as the most efficient medium for Spirulina platensis growth was in treatment P1 with waste media without the addition of technical fertilizer which produces a maximum density of $23.90 \mathrm{gL}^{-1}$ with a growth rate of $6.22 \%$ day $^{-1}$ and the ammonia removal $87.77 \%$ was the highest.

\section{Acknowledgement}

We thank to Sriwijaya University for funding this project through the "Penelitian Unggulan Profesi Dosen" with the research contract of No. 0109.26/UN9/SB3.LP2M.PT/2018.

\section{References}

[1] P.J.G. Henriksson, N. Tran, C.V. Mohan, C.Y. Chan, U-P. Rodriguez, S. Suri, L.D. Mateos, N.B.P. Utomo, S. Hall, M.J, Phillips, Indonesian aquaculture futures e Evaluating environmental and socioeconomic potentials and limitations, Journal of Cleaner Production 162, 1482-1490, 2017.

[2] Markou, G. and Georgakakis, D. Cultivation of filamentous cyanobacteria (blue-green algae) in agro-industrial wastes and wastewaters: A review. Applied Energy 88, 3389-3401, 2011.

[3] L.M. Andrade, C.J. Andrade, M. Dias, C.A.O. Nascimento, M.A. Mendes, Chlorella and Spirulina Microalgae as Sources of Functional Foods, Nutraceuticals, and Food Supplements; an Overview. MOJ Food Process Technol, 6(2), 2018.

[4] C.A. Ovando, J.C. de Carvalho, G.V. de Melo Pereira, P. Jacques, V.T. Soccol \& C.R. Soccol. Functional properties and health benefits of bioactive peptides derived from Spirulina: A review, Food Reviews International, DOI: 10.1080/87559129.2016.1210632, 2016.

[5] M.R. Andrade dan J.A.V. Costa. Mixotrophic cultivation of microalga Spirulina platensis using molasses as organic substrate. Elsevier B.V. Biochemical Engineering Laboratory, Department of Chemistry, Federal University Foundation of Rio Grande, 2007.

[6] M. Wijayanti, D. Jubaedah, R. Puspitasari, 2010. Spirulina production in fertilizer medium combined by tofu and latex liquid wastes. Proceeding International Seminar On Food And Agricultural Sciences-Isfas, 16-17 February 2010, pp 44-50.

[7] Suharyanto, Tri-Panji, S.Permatasari, \& K. Syamsu. Production of Spirulina platensis in continous photobioreactor using palm oil mill effluent media. Menara Perkebunan, 82(1), 1-9, 2014.

[8] Budiyono, I.. Syaichurrozi, S. Sumardiono, dan S.B. Sasongko. Production of Spirulina platensis Biomass Using Digested Vinasse as Cultivation Medium. Trends in Applied Sciences Research. 9 (2), 93-102, 2014

[9] S.C. Wuang, M.C. Khin, P.G.D. Chua, dan Y.D. Luo. Use of Spirulina biomass produced from treatment of aquaculture wastewater as agricultural fertilizers. Algal Research. 15, 59-64, 2016.

[10] S.M.S. Nogueira, J.S. Junior, H.D.Maia, J.P.S. Saboya, and W.R.L. Farias. Use of Spirulina platensis in treatment of fish farming wastewater. Revista Ciência Agronômica, 49(4), 599-606, 2018.

[11] A. Vonshak. Spirulina: Growth, physiology and biochemistry. In : A. Vhonshak (Ed.) platensis (Arthrospira) Physiology, cell-biology and biotechnology. (textbooks). Ben-Gurion University of the Negev. Israel. 1, 1-15, 1997.

[12] Hadiyanto, M.M.A. Nur, dan G.D. Hartanto, Cultivation of Chlorella sp. as Biofuel Sources in Palm Oil Mill Effluent (POME). Int. Journal of Renewable Energy Development. 1 (2), 45-49, 2012.

[13] N. Rahmawati, Yuliani dan E. Ratnasari. Pengaruh Pupuk Kompos Berbahan Campuran Limbah Cair Tahu, Daun Lamtoro dan Rumen Sapi sebagai Media Kultur terhadap Kepadatan Populasi Spirulina sp. Jurnal Lentera Bio. 1 (1), 17-23, 2012.

[14] A.W. Leksono, D. Mutiara, dan I.A. Yusanti. Penggunaan Pupuk Organik Cair Hasil Fermentasi dari Azolla pinnata Terhadap Kepadatan Sel Spirulina sp. Jurnal Ilmu-ilmu Perikanan dan Budidaya Perairan. 12 (1), 2017.

[15] T. Chrismadha, P. Lily, dan M. Yayah. Pengaruh Konsentrasi Nitrogen dan Fosfor terhadap Pertumbuhan, Kandungan Protein, Karbohidrat dan Fikosianin pada Kultur Spirulina fusiformis. Berita Biologi. 8 (3), 2006.

[16] D.R. Amanatin dan T. Nurhidayati, Pengaruh Kombinasi Konsentrasi Media Ekstrak Tauge (MET) dengan Pupuk Urea terhadap Kadar Protein Spirulina sp. Jurnal Sains dan Seni Pomits. 2 (2), 2337-3520, 2013.

[17] X. Yuan, A. Kumar, A.K Sahu,. dan S.J.Ergas. Impact of ammonia concentration on Spirulina platensis growth in an airlift photobioreactor. Bioresource Technology. 102, 3234-3239, 20

[18] H. Effendi. Telaah Kualitas Air, Kanisius, Yogyakarta, 2003. 